\title{
Penerapan Project Based Learning untuk Meningkatkan Pembelajaran Geometri Secara Online pada Mahasiswa PGSD di Masa Pandemi Covid-19
}

\author{
Wahyudi, Rokhmaniyah, Kartika Chrysti Suryandari \\ Universitas Sebelas Maret Surakarta \\ wahyudi@fkip.uns.ac.id
}

\section{Article History}

received 27/7/2021

\begin{abstract}
The Covid-19 pandemic period requires learning to be carried out online using various learning models to achieve learning objectives. For this reason, the objectives of this study are (1) to describe the steps of PjBL, (2) to improve Geometry learning, and (3) to find obstacles and solutions to the implementation of PjBL in online Geometry learning. The method used is Classroom Action Research which includes 4 steps, namely: planning, implementing, observing, and reflecting. The subjects of this study were 120 students of PGSD FKIP UNS Kebumen Campus for the Academic Year 2020/2021. Data collection techniques using observation, interviews, and tests. Data analysis includes data reduction, data presentation and conclusion drawing. The results of this study are (1) the steps for implementing PjBL in learning include (a) problem presentation, (b) project planning, (c) project activity schedule, (d) project implementation monitoring, (e) project results presentation, (f) evaluation of project results; (2) The implementation of PjBL can improve Geometry learning and (3) Obstacles in implementing PjBL are (1) learning resources are still lacking, (2) student learning independence is not optimal. Alternative solutions are (1) providing adequate learning resources, (2) monitoring learning activities on a regular basis. The conclusion of the research is PjBL can improve online geometry learning for students. The implication of this research is to increase students' motivation and activeness and to realize more varied learning.
\end{abstract}

Keywords: Project Based Learning, Geometry

\begin{abstract}
Abstrak
Masa pandemi Covid-19 mengharuskan pembelajaran dilaksanakan secara online dengan menggunakan berbagai model pembelajaran untuk mencapai tujuan pembelajaran. Untuk itu tujuan penelitian ini adalah (1) mendeskripsikan langkah PjBL, (2) meningkatkan pembelajaran Geometri, dan (3) menemukan kendala dan solusi penerapan PjBL pada pembelajaran Geometri secara online. Metode yang digunakan adalah Penelitian Tindakan Kelas yang meliputi 4 langkah, yaitu: perencanaan, pelaksanaan, observasi, dan refleksi. Subjek penelitian ini adalah 120 mahasiswa PGSD FKIP UNS Kampus Kebumen Tahun Akademik 2020/2021. Teknik pengumpulan data menggunakan observasi, wawancara, dan tes. Analisis data meliputi reduksi data, penyajian data dan penarikan kesimpulan. Hasil penelitian ini adalah (1) Langkah penerapan PjBL pada pembelajaran meliputi (a) penyajian masalah, (b) perencanaan projek, (c) penyusunan jadwal kegiatan projek, (d) monitoring pelaksanaan projek, (e) presentasi hasil projek, (f) evaluasi hasil projek; (2) Penerapan PjBL dapat meningkatkan pembelajaran Geometri dan (3) Kendala penerapan PjBL adalah (1) sumber belajar masih kurang, (2) kemandirian belajar mahasiswa belum optimal. Aternatif solusinya yaitu (1) menyediakan sumber belajar yang memadai, (2) memonitor kegiatan belajar secara berkala. Simpulan penelitian adalah PjBL dapat meningkatkan pembelajaran geometri secara online pada mahasiswa. Implikasi penelitian ini adalah meningkatkan motivasi dan keaktifan mahasiswa serta mewujudkan pembelajaran yang lebih variatif.
\end{abstract}

Kata Kunci: Project Based Learaning, Geometri 


\section{PENDAHULUAN}

Pendidikan pada abad 21 bertujuan untuk membangun kemampuan intelegensi peserta dalam pembelajaran agar mampu menyelesaikan permasalahan yang ada di sekitarnya. Membentuk intelegensi dalam dunia nyata tidak hanya dengan sekedar tahu dan paham, namun dituntut dapat memecahkan permasalahan yang dihadapi di sekitar lingkungan secara bermakna, relevan dan kontekstual. Pembelajaran kontekstual dapat melatih berpikir kritis, menguasai teknologi, kooperatif, dan berkolaborasi sangat diperlukan dalam memecahkan masalah. Tujuan yang ingin dicapai oleh peserta sangat beragam, misalnya keterampilan berpikir, keterampilan sosial, keterampilan psikomotor, dan keterampilan proses. Pada kurikulum pembelajaran bertujuan meningkatkan kualitas dalam imajinasi dan kreativitas; mengembangkan nilai-nilai kemanusiaan, mengembangkan potensi seseorang, mengembangkan pemikiran kritis, serta mengembangkan pribadi yang berkomitmen dan bertanggung jawab sesuai perkembangan jaman (Zhou, 2005). Selanjutnya, Eggen dan Kauchak (2012: 27-28) menegaskan bahwa standar untuk sekolah abad 21 atau abad digital untuk guru dan siswa berkaitan dengan penerapan teknologi dalam pembelajaran. Guru harus mampu mempersiapkan siswanya untuk hidup di abad digital. Salah satunya menggunakan pengetahuan mereka tentang materi pelajaran, pembelajaran dan teknologi untuk memfasilitasi pengalaman yang dipelajari siswa tingkat lanjut, kreativitas, dan inovasi dalam situasi tatap muka dan virtual. Salah satu cara yang dapat dilakukan guru adalah mengembangkan berbagai model pembelajaran dan teknologi pembelajaran untuk meningkatkan pemahaman dan keterampilan guru dalam proses pembelajaran secara tatap muka maupun virtual.

Lembaga Pendidikan Tenaga Kependidikan (LPTK) sebagai lembaga pendidikan tinggi mengemban misi untuk menghasilkan calon pendidik yang unggul di abad 21 . Calon pendidik unggul adalah pendidik yang dapat melaksanakan tugas pembelajaran dan pendidikan yang ditandai dengan kemampuan melaksanakan tugas pembelajaran aktif, inovatif, dan menyenangkan atau active learning in school (ALIS), harus disiapkan melalui suatu sistem pendidikan yang bermutu. Proses pendidikan calon pendidik di LPTK harus dirancang dan dikembangkan berdasarkan prinsip active learning in higher education (ALIHE) atau student activelearning (SAL) (Bintoro, 2014). Lembaga Pendidikan Tenaga Kependidikan juga perlu membekali mahasiswanya tentang berbagai model pembelajaran dan keterampilan menggunakan teknologi pembelajaran sesuai dengan situasi normal maupun situasi tidak normal seperti masa pandemi Covid-19.

Kasus Coronavirus Disease 2019 (COVID-19) pertama dilaporkan di Indonesia pada tanggal 2 Maret 2020 sejumlah dua kasus (WHO, 2020). Data 31 Maret 2020 menunjukkan kasus yang terkonfirmasi berjumlah 1.528 kasus dan 136 kasus kematian (Kemenkes, 2020). Tingkat mortalitas COVID-19 di Indonesia sebesar 8,9\%, angka ini merupakan yang tertinggi di Asia Tenggara (WHO, 2020). Menanggapi kondisi pandemi Covid-19 di Indonesia, maka pemerintah telah mengeluarkan Keputusan Presiden Republik Indonesia No: 11 Tahun 2020 tertanggal 31 Maret 2020 tentang Penetapan Kedaruratan Kesehatan Masyarakat Corona Virus Disease 2019 (Covid-19), yang isinya di antaranya: (1) Menetapkan Corona Virus Disease 2019 (Covid-19) sebagai jenis penyakit yang menimbulkan Kedaruratan Kesehatan Masyarakat, (2) Menetapkan Kedaruratan Kesehatan Masyarakat Corana Virus Disease 2019 (Covid-19) di Indonesia yang wajib dilakukan upaya penanggulangan sesuai dengan ketentuan peraturan perundang-undangan.

Menyikapi perkembangan penyebaran wabah penyakit infeksi Coronavirus (Covid 19) secara regional dan nasional, serta sebagai tindaklanjut dari Surat Edaran Rektor sebelumnya, Rektor UNS menerbitkan Surat Edaran No: 13/UN27/SE/2020 yanggal 26 Maret 2020 tentang Kebijakan Pemberlakuan Pembatasan Aktifitas di 
Kampus Universitas Sebelas Maret mulai tgl. 26 Maret s.d. 30 April 2020 dengan ketentuan, di antaranya adalah (1) kegiatan Belajar Mengajar tetap berjalan dengan pola pembelajaran daring yakni mahasiswa mengikuti proses pembelajaran online dari tempat tinggal masing-masing, (2) Seluruh pegawai UNS diupayakan melakukan pekerjaan dari tempat tinggal masing-masing. Selanjutnya Rektor UNS juga telah menerbitkan Surat Edaran No: 14/UN27/Se/2020 tanggal 26 Maret 2020 tentang Penyesuaian Perkuliahan, Pembimbingan, Ujian Tengah Semester, Ujian Tugas Akhir, Magang, Skripsi, Tesis, dan Disertasi di Universitas Sebelas Maret, yang isinya antara lain: (1) kuliah teori secara Daring (online) diperpanjang sampai dengan 30 April 2020, dan akan dievaluasi berdasarkan perkembangan Pandemi Covid-19. Proses pembelajaran dapat dilakukan dengan metode asinkron atau sinkron; (2) pembelajaran mata kuliah praktik yang dapat diakomodasi secara daring, maka pelaksanaannya menggunakan metode daring (teleconference). Berdasarkan Surat Edaran tersebut, maka semua kegiatan perkuliahan di Universitas Sebelas Maret Surakarta dilaksanakan secara Daring (Online).

Model pembelajaran Project Based Learning (PjBL) adalah model pembelajaran yang menggunakan masalah dunia nyata sebagai suatu konteks bagi siswa untuk belajar tentang cara berpikir kritis, bekerja secara kolaboratif, dan keterampilan memecahkan masalah sebagai tantangan atau pertanyaan yang harus dijawab, serta mengelola waktunya sendiri untuk dapat menyelesaikan atau menghasilkan suatu projek (Lambertus., dkk, 2014; Mahendra, 2017). Model pembelajaran ini dapat digunakan ketika pendidik ingin mengkondisikan pembelajaran aktif yang berpusat pada peserta didik dimana peserta didik memiliki pengalaman belajar yang lebih menarik dan menghasilkan sebuah karya berdasarkan permasalahan nyata (kontekstual) yang terjadi dalam kehidupan sehari-hari. Model pembelajaran ini juga dapat digunakan ketika pendidik ingin lebih menekankan pada keterampilan sains yaitu pada kegiatan mengamati, menggunakan alat dan bahan, menginterpretasikan, merencanakan projek, menerapkan konsep, mengajukan pertanyaan dan berkomunikasi dengan baik. Selain itu pendidik juga dapat menggunakan model PjBL ketika ingin mengembangkan kemampuan berfikir kreatif peserta didik dalam merancang dan membuat sebuah proyek yang dapat dimanfaatkan untuk mengatasi permasalahan secara sistematis. Sehingga model PjBL ini dapat membudayakan berpikir tingkat tinggi (High Order Thinking/HOT) dalam mengimplementasikan pembelajaran saintifik (Mengamati, Mengasosiasi, Mencoba, Mendiskusikan, dan Mengkomunikasikan) serta pembelajaran abad 21 (4C: Critical thinking, Collaboration, Creative, Communication) (Winarni, 2019).

Pembelajaran Geometri merupakan bagian penting pada mata kuliah Pembelajaran Geometri dan Aritmetika Sosial pada Program Studi PGSD FKIP UNS dengan bobot 3 SKS dan diberikan pada semester 4. Mata kuliah ini membahas tentang substansi dan metodologi dasar keilmuan geometri dan pengukuran, serta penerapannya dalam kehidupan sehari-hari. Adapun Capaian Pembelajaran Mata Kuliah (CPMK) Geometri dan Aritmetika Sosial adalah Mahasiswa mampu menerapkan pembelajaran SD dan pemecahan masalah tentang geometri datar, transformasi, geometri ruang, pengukuran, dan aritmetika sosial. Mata kuliah ini menuntut mahasiswa untuk menguasai materi pembelajaran dan terampil dalam melaksanakan praktik pembelajaran. Keterampilan melaksanakan pembelajaran dapat dicapai di antaranya dengan cara berlatih dan praktik langsung maupun dalam bentuk simulasi secara berkelanjutan. Untuk mencapai tujuan tersebut maka salah satu alternatif pembelajaran pada mata kuliah Geometri perlu dikembangkan model pembelajaran berbasis projek.

Dengan adanya masa Pandemi Covid-19, maka pembelajaran harus dilaksanakan secara daring. Hal ini berakibat kurang maksimal motode yang 
digunakan dan kurang efektif jalinan komunikasi antara mahasiswa dan dosen, karena antar mahasiswa maupun antara dosen dan mahasiswa tidak memungkinkan untuk bertatap muka secara langsung. Permasalahan lain yang ditemukan di lapangan adalah penerapan model pembelajaran yang kurang variatif, sehingga keaktifan mahasiswa dalam mengikuti perkuliahan perlu mendapat perhatian. Dampak akhir dari kondisi tersebut adalah kurang maksimalnya hasil belajar mahasiswa. Berdasarkan uraian tersebut di atas, maka tujuan penelitian ini adalah: (1) mendeskripsikan langkah penerapan PjBL untuk meningkatkan pembelajara Geometri, (2) meningkatkan pembelajaran Geometri, dan (3) mendeskripsikan kendala dan solusi penerapan PJBL untuk meningkatkan pembelajaran Geometri pada Mahasiswa Prodi PGSD FKIP UNS.

\section{METODE}

Penelitian ini menggunakan desain Penelitian Tindakan Kelas Model Kemmis dan Mc Taggart dengan 2 siklus. Setiap siklusnya terdiri dari 4 langkah, yaitu: (1) perencanaan, (2) pelaksanaan, (3) Observasi, dan (4) refleksi (Arikunto, 2013: 131). Subjek penelitian ini adalah mahasiswa PGSD FKIP UNS Kampus Kebumen yang menempuh Mata kuliah Geometri dan Aritmetika Sosial pada semester IV Tahun Akademik 2020/2021, yaitu sebanyak 120 mahasiswa. Sumber data yang digunakan dalam penelitian ini adalah mahasiswa, teman sejawat dosen, dan dokumen. Adapun teknik pengumpulan data yang digunakan pada penelitian ini adalah observasi, wawancara, angket, dan tes. Validitas data dalam penelitian ini diperoleh melalui triangulasi sumber, triangulasi teknik, dan triangulasi ahli. Triangulasi sumber yang digunakan berasal dari mahasiswa, teman sejawat dosen, dan dokumen. Triangulasi teknik yang digunakan meliputi kegiatan observasi, wawancara, dan Tes. Adapun triangulasi ahli melibatkan teman sejawat dosen yang berlatar belakang pendidikan Matematika. Analisis data yang digunakan adalah analisis kualitatif yang meliputi tiga alur kegiatan yang terjadi secara bersama-sama dan terus-menerus selama dan setelah pengumpulan data yaitu reduksi data, penyajian data dan penarikan kesimpulan atau verifikasi (Miles \& Huberman, 1992: $15-21$ ).

\section{HASIL DAN PEMBAHASAN}

\section{Penerapan Project Based Learning pada Pembelajaran Geometri}

Langkah-langkah implementasi model Project Based Learning meliputi: (1) penyajian masalah, (2) penyusunan perencanaan projek, (3) penyusunan jadwal kegiatan projek, (4) monitoring pelaksanaan projek, (5) presentasi hasil projek, (6) evaluasi hasil projek.

Pada langkah penyajian masalah, dosen menyajikan masalah berupa pertanyaan esensial pada awal pembelajaran. Kegiatan pembelajaran dimulai dengan memberikan pertanyaan menantang kepada mahasiswa. Pertanyaan yang akan menggiring mahasiswa pada konteks pembelajaran berbasis projek dan memberikan tugas kepada mahasiswa untuk melakukan sebuah aktifitas yang terkontrol. Topik penugasan sesuai dengan dunia nyata yang relevan untuk mahasiswa dan dimulai dengan sebuah investigasi mendalam.

Pada langkah penyusunan perencanaan Projek, dosen dan mahasiswa berkolaborasi menyusun perencanaan projek yang akan dikerjakan. Penetapan kegiatan-kegiatan yang akan dilakukan dalam projek dari tahap awal hingga akhir projek.

Pada langkah penyusunan jadwal kegiatan projek, dosen dan mahasiswa secara kolaboratif menyusun jadwal aktivitas dalam menyelesaikan projek. Tujuan kegiatan ini adalah memberikan pemahaman kepada mahasiswa bahwa untuk melakukan sebuah 
projek yang besar, sebuah kelompok kerja membutuhkan jadwal kerja yang baik agar projek dapat dilaksanakan sesuai rencana.

Pada langkah monitoring pelaksanaan Projek, dosen bertanggung jawab untuk melakukan monitoring terhadap aktivitas mahasiswa selama menyelesaikan projek. Pengawasan ini berfungsi bukan hanya sebagai sebuah kontrol kerja namun juga merupakan sebuah proses pembimbingan. Monitoring dilakukan dengan memberikan fasilitas penuh kepada mahasiswa untuk melakukan aktifitasnya dengan sempurna.

Pada langkah presentasi hasil projek, mahasiswa diminta menyajikan hasil projeknya. Langkah ini digunakan dosen untuk mengetahui progress kerja mahasiswa dalam melaksanakan projeknya. Pada langkah ini, penilaian dapat dilakukan terhadap proses dan hasil kerja mahasiswa dalam projeknya. Penilaian dilakukan untuk mengukur ketercapaian kompetensi mahasiswa, memberi umpan balik tentang tingkat pemahaman yang sudah dicapai mahasiswa, serta dapat membantu dosen dalam menyusun strategi pembelajaran berikutnya.

Pada langkah evaluasi hasil projek, dosen dan mahasiswa melakukan refleksi terhadap aktivitas dan hasil projek yang sudah dijalankan. Proses refleksi bertujuan untuk menemukan kelebihan dan kekurangan pada pelaksanaan projek, serta dapat digunakan untuk menentukan tindak lanjut kegiatan pembelajaran berikutnya. Kegiatan refleksi dapat dilakukan secara individu maupun kelompok.

Berdasarkan hasil tindakan yang telah dilaksanakan selama 2 siklus, maka diperoleh data tentang penerapan PjBL pada pembelajaran geometri sebagai berikut.

\begin{tabular}{|c|c|c|c|c|}
\hline & Langkah PjBL & $\begin{array}{l}\text { Skor } \\
\text { Siklus } 1\end{array}$ & $\begin{array}{l}\text { Skor } \\
\text { Siklus } 2\end{array}$ & Rerata \\
\hline 1. & Menyajikan masalah & 3,15 & 3,30 & 3,23 \\
\hline 2. & Menyusun perencanaan projek & 3,20 & 3,45 & 3,33 \\
\hline 3. & Menyusun jadwal kegiatan projek & 3,10 & 3,45 & 3,28 \\
\hline 4. & Memonitor pelaksanaan projek, & 3,25 & 3,60 & 3,43 \\
\hline 5. & Mempresentasikan hasil projek & 3,15 & 3,65 & 3,40 \\
\hline 6. & Mengevaluasi hasil projek. & 3,15 & 3,75 & 3,45 \\
\hline & Rerata & 3,17 & 3,53 & 3,35 \\
\hline
\end{tabular}

Berdasarkan tabel 1 di atas terlihat bahwa penerapan PjBL pada pembelajaran Geometri pada siklus I tentang Gemoetri Datar masih kurang maksimal. Hal ini terjadi karena Dosen dan mahasiswa belum terbiasa dengan model pembelajaran PjBL. Dari ke enam langkah PjBL yang diterapkan skor minimal terdapat pada langkah ke 3 , yaitu penyusunan jadwal kegiatan projek. Pada langkah ini ternyata belum didukung dengan sarana pembelajaran yang memadai, apalagi perkuliahan dilaksanakan secara daring, sehingga penyusunan jadwal kegiatan projek mengalami kendala. Sedangkan skor tertinggi pada langkah PjBL siklus 1 terdapat pada langkah ke 4, yaitu memonitor pelaksanaan projek. Ini terjadi karena stiap kegiatan perkuliahan sekaligus dilakukan monitoring projek yang telah dikerjakan oleh mahasiswa. Pada siklus 1 tersebut diperoleh skor rata-rata dalam penerapan $\mathrm{PjBL}$ pada pembelajaran Geometri sebesar 3,17 , yang berarti sudah baik, namun perlu peningkatan lagi pada siklus 2 .

Langkah penerapan PjBL pada siklus II digunakan pada materi pembelajaran Geometri Ruang. Secara umum telah mengalami peningkatan dari siklus 1, yaitu 3,53. Dari keenam langkah PjBL, yang mendapatkan skor terendah adalah langkah ke 1, yaitu menyajikan masalah. Hal ini terjadi karena pemahaman terhadap masalah yang akan dipecahkan masih kurang, sehingga fokus masalah perlu mendapat perhatian. Skor tertinggi terdapat pada langkah ke 6, yaitu mengevaluasi hasil projek. Dosen dan mahasiswa telah melakukan kontrak kuliah tentang komponen penilaian hasil projek, 
sehingga proses penilaian dilaksanakan secara terbuka. Dengan demikian hasil penilaiannya dapat diterima dan dimaklumi semua pihak.

Berdasarkan uraian di atas, dapat disimpulkan bahwa langkah-langkah penerapan model PjBL meliputi: (1) menyajikan masalah, (2) menyusun perencanaan projek, (3) menyusun jadwal kegiatan projek, (4) memonitor pelaksanaan projek, (5) mempresentasikan hasil projek, (6) mengevaluasi hasil projek (Sani, 2014: 181); (Wadji, 2017: 86-87).

\section{Peningkatan Hasil Belajar Geometri berbasis Project Based Learning}

Hasil belajar Gemoetri berbasis PjBL terdiri dari tiga skor, yaitu skor Pretest, skor siklus 1 dan skor siklus 2. Skor Prestest digunakan untuk mengetahui kemampuan awal mahasiswa terhadap penguasaan konsep dan prosedur pembelajaran geometri di sekolah dasar. Skor siklus 1 merupakan skor hasil belajar dengan penerapan PjBL pada materi Geometri Datar. Sedangkan skor siklus 2 merupakan skor hasil belajar penerapan PjBL Geometri Ruang. Berdasarkan hasil tindakan selama 2 siklus, maka diperoleh data skor hasil belajar sebagai berikut.

\begin{tabular}{|c|c|c|c|c|}
\hline No & Interval Skor & $\begin{array}{c}\text { Skor } \\
\text { Pretes }\end{array}$ & $\begin{array}{c}\text { Skor } \\
\text { Siklus } 1\end{array}$ & $\begin{array}{c}\text { Skor } \\
\text { Siklus } 2\end{array}$ \\
\hline 1 & $00-09$ & 0 & & \\
\hline 2 & $10-19$ & 0 & & \\
\hline 3 & $20-29$ & 11 & & \\
\hline 4 & $30-39$ & 36 & & \\
\hline 5 & $40-49$ & 41 & 2 & \\
\hline 6 & $50-59$ & 23 & 0 & 1 \\
\hline 7 & $60-69$ & 8 & 55 & 11 \\
\hline 8 & $70-79$ & 1 & 57 & 46 \\
\hline 9 & $80-89$ & & 6 & 49 \\
\hline 10 & $90-100$ & & & 13 \\
\hline & Jumlah & 120 & 120 & 120 \\
\hline & Rerata & 43,63 & 71,21 & 81,38 \\
\hline & Terendah & 22 & 49 & 59 \\
\hline & Tertinggi & 70 & 84 & 94 \\
\hline
\end{tabular}

Dari tabel 2 di atas dapat dimpulkan bahwa pada skor Pretest, dari 120 mahasiswa terdapat 111 mahasiswa (92,5\%) yang belum tuntas Materi Geometri sekolah dasar, dan 9 mahasiswa $(7,5 \%)$ yang telah tuntas materi tersebut. Skor tertingg dari pretes adalah 70 , skor terendahnya adalah 22 , dan skor reratanya adalah 43,63 .

Pada siklus 1 penerapan PjBL dengan materi Geometri Datar, diperoleh data dari 120 mahasiswa, terdapat 118 mahasiswa (98,33\%) yang telah tuntas materi tersebut. Sedangkan 2 mahasiswa (1,67\%) belum teuntas. Skor teringgi 84 dan skor terendahnya adalah 49, dengan rerata skor siklus 1 adalah 71,21. Dari data pretest dan skor siklus 1 tersebut maka terlihat bahwa penerapan PjBL pada pembelajaran Geometri dapat meningkatkan hasil belajar mahasiswa. Selanjutnya pada siklus 2 dengan penerapan PjBL pada materi Geometri Ruang diperoleh data dari 120 mahasiswa tedapat 119 mahasiswa $(99,16 \%)$ yang telah tuntas dan 1 mahasiswa $(0,84 \%)$ yang belum tuntas. Skor tertinggi pada siklus 2 adalah 94, skor terendah adalah 59, dan rerata skor pada siklus 2 adalah 81,38.

Pada implementasi Project Based Learning, dosen bersama mahasiswa saling berkolaborasi mulai dari kegiatan awal sampai dengan kegiatan akhir. Selain itu, dosen 
dan mahasiswa memiliki tugas dan tangung jawab masing-masing dan harus berjalan bersama selama projek berlangsung. Dosen harus menyiapkan sarana yang diperlukan dalam pembelajaran dan mahasiswa harus melaksanakan projeknya dengan penuh tanggung jawab. Selain rasa tanggung jawab, mahasiswa dituntut untuk mengembangkan komunikasi, kolaborasi, kreativitas dalam kelompok maupun antarkelompok kerja. Dengan demikian penerapan Project Based Learning dapat terlaksana dengan baik. Pada pelaksanaan projek, mahasiswa. Berdasarkan uraian tersebut, maka dapat disimpulkan bahwa dengan penerapan PjBL dapat meningkatkan pembelajaran Geometri pada mahasiswa secara signifikan (Made \& Wena, 2011: 147); Sani (2015: 177); Mayangsari (2017: 33); Prabowo (2012: 8); Kecuali itu, penerapan $P J B L$ juga dapat meningkatkan aktivitas dan motivasi belajar, karena dengan melaksanakan semua tahapan projek yang dilaksanakan, mahasiswa juga berusaha untuk memenuhi tanggung jawabnya pada saat presentasi hasil projeknya (Hapsari, dkk. 2019: 102-122); Hidayah dkk., (2017: 157).

Dengan hasil tersebut, maka penerapan Project Based Learning pada materi Geometri perlu terus ditingkatkan sehingga proses dan hasil belajar mahasiswa dapat meningkat secara optimal. Bahan ajar yang digunakan pada penerapan PjBL tersebut adalah bahan ajar yang telah disusun sesuai dengan tujuan pembelajaran. Namun demikian bahan ajar tesebut masih perlu terus disempurnakan dan dilengkapi, agar lebih detail dan lebih mudah diterapkan pada pembelajaran dengan penerapan model Project Based Learning.

\section{Kendala dan Solusi Penerapan Project Based Learning}

Untuk memperoleh informasi secara lengkap tentang kendala yang dihadapi mahasiswa tentang Penerapan PjBL pada pembelajaran Geometri, maka digunakan beberapa alat pengumpulan data, yaitu observasi, wawancara, dan angket. Dari hasil isian angket yang dilakukan melalui google form tersebut, dapat didetksi adanya kendala dalam penerapan model pembelajaran $P j B L$ secara daring, di antaranya adalah (1) sumber belajar dan media belajar yang masih kurang, (2) kemandirian belajar mahasiswa belum optimal, (3) sinyal internet belum sepenuhnya stabil di berbagai daerah tempat tinggal mahasiswa Murfiah (2017: 138). Berdasarkan kendala tersebut maka alternatif solusinya, yaitu (1) menyediakan sumber belajar yang memadai melalui perpustakaan atau sumber belajar online, (2) meningkatkan kemandirian belajar dengan cara memonitor kegiatan belajar secara berkala, (3) penyediaan jaringan internet yang memadai atau mencari lokasi dengan jaringan internet yang stabil.

\section{SIMPULAN}

Berdasarkan hasil analisis data dan pembahasan tentang penerapan PjBL pada pembelajaran Geometri pada Mahasiswa PGSD FKIP UNS, dapat disimpulkan sebagai berikut.

1. Langkah penerapan model pembelajaran Project Based Learning (PjBL) meliputi: (1) penyajian masalah, (2) penyusunan perencanaan projek, (3) penyusunan jadwal kegiatan projek, (4) monitoring pelaksanaan projek, (5) presentasi hasil projek, (6) evaluasi hasil projek.

2. Penerapan Model Pembelajaran Project Based Learning (PjBL) dapat meningkatkan pembelajaran Geometri pada mahasiswa PGSD FKIP UNS.

3. Kendala yang dihadapi pada penerapan PjBL adalah: (1) sumber belajar dan media belajar yang masih kurang, (2) kemandirian belajar mahasiswa belum optimal, (3) sinyal jaringan internet kurang stabil di berbagai daerah tempat tinggal mahasiswa. Berdasarkan kendala tersebut maka alternatif solusinya, yaitu (1) menyediakan 
sumber belajar yang memadai berupa buku atau sumber belajar online, (2) meningkatkan kemandirian belajar dengan cara memonitor kegiatan belajar secara berkala, (3) penyediaan jaringan internet yang memadai atau mencari lokasi dengan jaringan internet yang stabil.

Penelitian ini adalah tentang penerapan PjBL pada pembelajaran Geometri sebagai alternatif model pembelajaran pada masa Pandemi Covid-19. Implikasi penelitian ini adalah dapat meningkatkan motivasi dan keaktifan mahasiswa serta mewujudkan pembelajaran yang lebih variatif. Untuk itu hasil penelitian ini dapat direkomendasikan kepada peneliti lain untuk melakukan penelitian lebih lanjut tentang penerapan PjBL pada mata kuliah lain.

\section{DAFTAR PUSTAKA}

Arikunto, S. (1992). Prosedur Penelitian Suatu Pendekatan Praktik. Jakarta: Penerbit Rineka Cipta.

Bintoro, Totok. (2014). Pengembangan Kurikulum LPTK \& Kaitannya dengan KKNI. Makalah disampaikan pada lokakarya Desain Kurikulum LPTK

Berkelanjutan PPG dengan Mengacu KKI di Universitas Muhammadiyah Surakarta, 10 April 2014.

Eggen, P.D., \& Kauchak D. P. (2006). Strategies for teachers: Teaching content and thinking skills. Boston: Allyn \& Bacon.

Hapsari, D.I; Gamaliel S.A; Susiani. (2019). Penerapan project based learning untuk meningkatkan motivasi belajar matematika. Jurnal Riset dan Inovasi Pendidikan JARTIKA. 2 (1) $102-112$.

Hidayah, N; Satrianawati. (2017). Pengembangan Model Project Based Learning terhadap Motivasi dan Aktivitas Belajar Siswa. Jurnal AdMathEdu. 7 (2) 157 176.

Kementerian Kesehatan Republik Indonesia. Info Infeksi Emerging Kementerian Kesehatan RI [Internet]. (2020) [updated 2020 March 30; cited 2020 March 31]. Available from: https://infeksiemerging.kemkes.go.id/

Lambertus., Bey, A., Anggo, M., Fahinu., Sudia M., \& Kadir. (2014) Developing Skills Resolution Mathematical Primary School Students. International Journal of Education and Researc. 2 (10) 601-614.

Mahendra I. W. E. (2017) Project Based Learning Bermuatan Etnomatematika dalam Pembelajaran Matematika. Jurnal Pendidikan Matematika. 6 (1), 111-112

Mayangsari, Sizillia Noranda. (2017). Peningkatan Hasil Belajar Mahasiswa dengan Project Based Learning (Pjbl). LIKHITAPRAJNA Jurnal IImiah. 19 (2) 33 - 43)

Miles, Mattew B. \& Huberman, A. Michael. (1992). Analisis Data Kualitatif (Terjemahan oleh Tjetjep Rohendi Rohidi). Jakarta: Universitas Indonesia.

Murfiah, U. (2017). Pembelajaran Terpadu (Teori \& Praktik Terbaik di Sekolah). Bandung: PT Refika Aditama.

Prabowo, Ardi. (2012). Pembelajaran Berbasis Proyek Untuk Meningkatkan Pemahaman Mahasiswa atas Permasalahan Statistika pada Perkuliahan Studi Kasus dan Seminar. Kreano, Jurnal Pendidikan Matematika FPMIPA UNNES. 3 (2) $1-9$.

Sani. R, A. (2015). Pembelajaran Saintifik Untuk Implementasi Kurikulum 2013. Jakarta: PT Bumi Aksara

Surat Edaran Rektor UNS No: 13/UN27/SE/2020 tanggal 26 Maret 2020 tentang Kebijakan Pemberlakuan Pembatasan Aktifitas di Kampus Universitas Sebelas Maret.

Surat Edaran Rektor UNS No: 14/UN27/Se/2020 tanggal 26 Maret 2020 tentang Penyesuaian Perkuliahan, Pembimbingan, Ujian Tengah Semester, Ujian Tugas Akhir, Magang, Skripsi, Tesis, dan Disertasi di Universitas Sebelas Maret. 
Wadji, F. (2017). Implementasi Project Based Learning (PBL) dan Penilaian Autentik dalam Pembelajaran Drama Indonesia. Jurnal Pendidikan Bahasa dan Sastra. 17 (1) 81-97.

Wena \& Made. (2011). Strategi pmbelajaran Inovatif Kontemporer. Jakarta: PT Bumi Aksara.

Winarni (2019) Peningkatan Kemampuan Berpikir Tingkat Tinggi Menggunakan Huruf Kapital Malalui Penerapan model Pjbl di SDIT Izzatul Islam Getasan. Jurnal Manajemen Pendidikan. 14 (1) 22-23.

World Health Organization. Situation Report - 42 [Internet]. (2020) [updated 2020 March 02; cited 2020 March 15]. Available from: https://www.who.int/docs/default-source/coronaviruse/situationreports/20200302-sitrep-42-covid-19. pdf?sfvrsn=224c1add 2.

World Health Organization. Naming the coronavirus disease (COVID-19) and the virus that causes it [Internet]. Geneva: World Health Organization; 2020 [cited 2020 March 29]. Available from: https://www.who.int/emergencies/diseases/novelcoronavirus-2019/technicalguidance/naming-the-coronavirusdisease-(covid-2019)-and-the-virus-thatcauses-it.

World Health Organization. Coronavirus disease 2019 (COVID-19) Situation Report 70 [Internet]. WHO; 2020 [updated 2020 March 30; cited 2020 March 31]. Available from: https://www.who.int/docs/default-source/coronaviruse/situationreports/20200330sitrep-70-covid-19.pdf?sfvrsn=7e0fe3f8 2

Zhou, N. 2005. Four 'Pillars of Learning'for the Reorientation and eorganization of Curriculum: Reflections and Discussions. AsiaPacific Programme of Educational Innovation for Development (APEID), at UNECO Asia and Pacific Regional Bureau.

(Online), (http://www.be.unesco.org/cops/Competencies/PillarsLearningZhou.pdf), diakses 18 Januari 2012. 